\title{
IIIISGUC.ORG
}

"iş, GÜÇ" ENDÜSTRI iLişKILERI VE INSAN KAYNAKLARI DERGISi

"IS, GUC" INDUSTRIAL RELATIONS AND HUMAN RESOURCES JOURNAL

\section{Tunçbilek Kömür İşletmelerinde Özelleştirmenin Madencilik, İşçilik ve Tunçbilek Üzerine Etkileri}

\author{
Doç. Dr. Sibel KALAYCIOĞLU
}

Orta Doğu Teknik Üniversitesi, Sosyoloji Bölümü

\section{Doç. Dr. Kezban ÇELİK}

On Dokuz Mayıs Üniversitesi, Sosyoloji Bölümü

Ocak/January 2014, Cilt/Vol: 16, Sayı/Num: 1, Page: 01-19

ISSN: 1303-2860, DOI: 10.4026/1303-2860.2014.0243.x

Makalenin on-line kopyasına erişmek için / To reach the on-line copy of article:

http://www.isguc.org/?p=article\&id=530\&cilt=16\&sayi=1\&yil=2014

Makale İçin İletişim/Correspondence to:

Doç.Dr.Sibel KALAYCIOĞLU / Email: ksibel@metu.edu.tr 


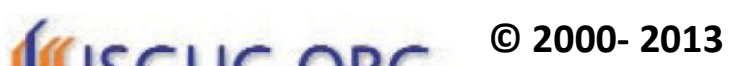 \\ "İş,Güç" Endüstri ilişkileri ve İnsan Kaynakları Dergisi "Işs,Güç" Industrial Relations and Human Resources Journal
}

\author{
Ocak/January 2014, Cilt/Vol: 16, Say1/Num: 1, \\ Sayfa/Page: 01-19, DOI: 10.4026/1303-2860.2014.0243.x
}

"İş,Güç" Endüstri İlişkileri ve İnsan Kaynakları Dergisi, yılda dört kez yayınlanan hakemli, bilimsel elektronik dergidir. Çalışma hayatına ilişkin makalelere yer verilen derginin temel amact; belirlenen alanda akademik gelişime ve paylaşıma katkıda bulunmaktır.

"İş,Güç" Endüstri İlişkileri ve İnsan Kaynakları Dergisi'nde, 'Türkçe' ve 'İngilizce' olarak iki dilde makale yayınlanmaktadır. "İş,Güç" Endüstri İlişkileri ve İnsan Kaynakları Dergisi, ulusal ve uluslararası birçok indekste taranmaktadır. (Cabell's Directories, Ebsco Socindex, Index Islamicus, Index Copernicus International, Worldwide Political Science Abstracts, Sociological Abstract, Ulakbim Sosyal Bilimler Veritabanı, ASOS Index)

Editörler Kurulu / Editorial Board Aşkın Keser (Uludă̆ University) K.Ahmet Sevimli (Uludă̆ University) Şenol Baştürk (Uludağ University)

\section{Editör / Editor in Chief}

Şenol Baştürk (Uludăg University)

\section{Uygulama / Design}

Yusuf Budak (Kocaeli University)

Tarandığı Indeksler / Indexes ASOS INDEX

CABELL'S DIRECTORIES EBSCO SOCINDEX Index ISLAMICUS Index COPERNICUS Int. Sociological Abstract ULAKBİM Sosyal Bilimler Veritanı

Worldwide Political Science Abstracts

\author{
Yayın Kurulu / Editorial Board \\ Dr.Şenol Baştürk (Uludă̆ University) \\ Yrd.Doç.Dr.Zerrin Fırat (Uludă̆ University) \\ Doç.Dr.Aşkın Keser (Uludă̆ University) \\ Prof.Dr.Ahmet Selamoğlu (Kocaeli University) \\ Yrd.Doç.Dr.Ahmet Sevimli (Uludağ University) \\ Doç.Dr.Abdulkadir Şenkal (Kocaeli University) \\ Doç.Dr.Gözde Yılmaz (Marmara University) \\ Yrd.Doç.Dr.Memet Zencirkıran (Uludağ University)
}

Uluslararası Danışma Kurulu / International Advisory Board
Prof.Dr.Ronald Burke (York University - Kanada)
Assoc.Prof.Dr.Glenn Dawes (James Cook University - Avustralya)
Prof.Dr.Jan Dul (Erasmus University - Hollanda)
Prof.Dr.Alev Efendioğlu (University of San Francisco - ABD)
Prof.Dr.Adrian Furnham (University College London - Ingiltere)
Prof.Dr.Alan Geare (University of Otago - Yeni Zellanda)
Assoc. Prof. Dr. Diana Lipinskiene (Kaunos University - Litvanya)
Prof.Dr.George Manning (Northern Kentucky University - ABD)
Prof.Dr.Mustafa Özbilgin (Brunel University - UK)
Assoc. Prof. Owen Stanley (James Cook University - Avustralya)
Prof.Dr.Işık Urla Zeytinoğlu (McMaster University - Kanada)

Ulusal Danışma Kurulu / National Advisory Board

Prof.Dr.Yusuf Alper (Uludă̆ University)

Prof.Dr.Veysel Bozkurt (İstanbul University)

Prof.Dr.Toker Dereli (Işık University)

Prof.Dr.Nihat Erdoğmuş (İstanbul Şehir University)

Prof.Dr.Ahmet Makal (Ankara University)

Prof.Dr.Süleyman Özdemir (İstanbul University)

Prof.Dr.Ahmet Selamoğlu (Kocaeli University)

Prof.Dr.Nadir Suğur (Anadolu University)

Prof.Dr.Nursel Telman (Maltepe University)

Prof.Dr.Cavide Uyargil (Istanbul University)

Prof.Dr.Engin Yildırım (Anayasa Mahkemesi)

Doç.Dr.Arzu Wasti (Sabancı University)

Dergide yayınlanan yazılardaki görüşler ve bu konudaki sorumluluk yazarlarına aittir.

Yayınlanan eserlerde yer alan tüm içerik kaynak gösterilmeden kullanılamaz.

All the opinions written in articles are under responsibilities of the authors.

The published contents in the articles cannot be used without being cited. 


\title{
Tunçbilek Kömür İşletmelerinde Özelleştirmenin Madencilik, İşçilik ve Tunçbilek Üzerine Etkileri
}

\author{
Doç. Dr. Sibel KALAYCIOĞLU \\ Orta Doğu Teknik Üniversitesi, Sosyoloji Bölümü \\ Doç. Dr. Kezban ÇELİK \\ On Dokuz Mayıs Üniversitesi, Sosyoloji Bölümü
}

\begin{abstract}
This article examines the impact of structural changes in the local, national and global dynamics on mine workers' experiences in Tunçbilek coal mine in Kütahya, Turkey. In this context, this paper, based on a field research conducted in 2011 in Tunçbilek, Kütahya, focuses on the changing experiences of coal workers through change. In the field research 40 workers who are still working in Tunçbilek Coal Mine are interviewed in-depth. This coal mine was operated by the state as a state owned industry from 1940s until 2000s. During the 2000s, changing legislation about mining and energy policies in Turkey, a privatization and de-nationalization process of mines has started. Coal mine, traditionally known in the region as a regular and wellpaid work, became the source of flexible and poorly paid work. The safety concern of the public enterprise is replaced by a productivity focus. A gap between private and public sector workers in terms of rights and benefits have emerged. All these findings indicate the emergence of a new coal worker with a new class culture and conflicts.
\end{abstract}

Keywords: Coalmining, Privatization, Impact on Workmanship and Work Process, New Coalmining.

Özet:

Bu çalışma, madencilik sektöründe meydana gelen yerel, ulusal ve küresel değişimlerin Tunçbilek Kömür İşletmelerinde çalışan işçiler üzerine etkilerini ele almaktadır. Bu kapsamda Tunçbilek Kömür Işsletmelerinde çalışan 40 işçi ile yapılan derinlemesine görü̈şmelere dayanmaktadır. Tunçbilek Kömür İşletmeleri 1940-2000'li yıllar arasında devlet eliyle işletilmiş, 2000 'li yıllarda meydana gelen değişimlerle birlikte özelleştirilmeye başlamıştır. Geleneksel olarak "iyi ücretli" ve "düzenli" olan maden iş̧̧iliği "düşük ücretli" ve 'geçici/mevsimsel" hale gelmiştir. Kamunun ilk önceliklerinden olan "i̧̧ güvenliği”" özel girişimciliğin sektöre katılması ile yerini "üretkenliğe" birakmış̧ır. Böylece kamu-özel sektörde iş̧̧i olmak arasındaki fark gün geçtikçe açılmıştır. Tunçbilek kömür işletmesi çalışması bize madenlerin özelleştirilmesi, yeni teknolojilerin gelmesi ve iç göç yolu ile bölgeye gelen taşeron iş̧̧iliğin ortaya çıkardiğı değişen iş̧̧ilik biçimlerini ve işçiler arasındaki ayrışmanın nedenlerini göstermektedir. Yeni toplumsal yaşamda bu ayrışmanın izlerini taşımakta ve eski ve yeni işçilerin oluşturduğu mahallelerde farklı yaşam biçimleri ve pratikleri oluşmakta, birbirine benzeyen ve biz duygusu olan işçilik giderek yok olmaktadır.

Anahtar Kelimeler: Maden İş̧̧iliği, Özelleştirme, Değişen İş̧̧ilik, Değişen İş Süreçleri, Yeni Madencilik. 


\section{Giriş}

\begin{abstract}
"Hiç kimse madencilere ilişkin yirminci yüzyılda yapılan çalışmalarda madencilerin yaşamı, bireysel politikalar, toplumsal hafıza, mitler ve kültürel cemaatlerin önemini görmezden gelemez...Özel mülkiyet olarak işletilen madencilikte çalışanların katlanmak zorunda kaldıkları güçlükleri içeren geçmiş, nesilden nesile aktarılmaktadır. Böylece madencilik kadar geçmişine tutsak olan bir başka endüstri dalı yoktur denilebilir. Bu geçmiş, madenciliğin kamulaştırılması ile yeni endüstri ilişkilerinin oluşturulmasında taze bir başlangıç sunamamıştır" (Supple, 1987: 682-3).
\end{abstract}

Dünya ekonomisinde 1970'li yıllarda ortaya çıkan durgunluk ile birlikte, mevcut ekonomik politikalar ve bu politikaların dayandığı teorik temeller sorgulanmaya başlanmıştır (Petras ve Veltmayer, 2001; Bello, Bullard ve Malhotra, 2000; Baiman, Boushey ve Saunders, 2000). 1929 bunalımı ile başlayan gelişmelerin tam tersi bir hareket olarak ortaya çıkan ve kamu açıklarının en temel nedeni olarak kamu işletmelerinin verimsizliğini gören anlayış, kamu işletmelerinin özelleştirilmesi akımını 1970'li yılların sonlarından itibaren öncelikle İngiltere'den ve kamu maden işletmelerinden başlatmıştır. Küresel rekabet, değişen enerji politikaları ve bunlara bağlı çalışma ilişkileri sermaye yanlı ekonomi politikaların gelişmesine yol açmıştır (Gibbon ve Bromley, 1990; Leman ve Winterton, 1991; Parry et. Al., 1997).

Gerek yeni piyasa yapılanması nedeniyle devlet yardımlarının çekilmesi, gerekse çevresel kaygılar, Avrupa'nın ekonomik ve toplumsal gelişmesinde önemli rol oynayan kömür endüstrisinin, büyük oranda gerilemesine ve özel girişimciliğin eline geçmesine neden olmuştur. Yeniden yapılandırma, karlı görünmeyen kömür işletmelerinin kapatılması, sektördeki kamu kuruluşlarının tasfiyesi ya da özelleştirilmesi planı; ve kömür sektörüne devlet yardımlarının kesilmesi şeklinde olmuştur (WEC, 2000). Söz konusu gelişmelerin Türkiye madencilik sektörüne yansımaları, özellikle 1990'lardan itibaren hız kazanmıştır.

Sanayi devriminin hızını ve gelişimini temelden etkilemiş olan ve belki bununla mümkün kılan kömür halen dünya ekonomileri üzerinde önemli etki yapmaktadır. Bununla beraber, diğer pek çok endüstri gibi kömür endüstrisinin de, içinde bulunduğumuz küreselleşme sürecinden önemli ölçüde etkilendiği, son 30 yıldır gerek küresel gerekse ulusal düzeylerde belirli değişim süreçlerine maruz kaldığı gözlenmektedir. Bu değişimler ve değişimlerin iş ve işçilik üzerine etkilerine bakmak madencilik sektörünün tüm emek tarihi çalışmaları açısından özel bir önemi olduğu için gerekli gözükmektedir. Bunun nedeni, madencilik ve özellikle de kömür madenciliği faaliyet alanının tarih boyunca işçilerin çalışma koşullarının en kötü olduğu ve uzun yüzyıllar süren mücadelelere sahne olan bir kesim olmasıdır. Nitekim yeryüzü ölçeğinde ilk sosyal politika tedbirleri de madencilik sektöründen başlayarak gerçekleştirilmiştir (Tamzok, 2004; Makal, 2008:28).

\section{Türkiye'de bir sektör olarak madencilik}

Osmanlı İmparatorluğu döneminde Osmanlı donanmasının buharliya çevrilmesi ve devlet tesislerinde yakıt gereksinimini sağlamak amacıyla özellikle 19. yüzyıl ortalarından itibaren kömür madenlerinin işletilmesi önemli bir konu haline gelmiştir. Artan gereksinime bağlı olarak başta Ereğli Kömür Havzası olmak üzere çalışma alanları ve madencilik faaliyetleri gelişmeye başlamıştır (Makal, 2004:123). Bu dönemde madencilik sektörü çoğunlukla yabancı ve azınlık sermayesi eliyle işletilmiştir. 1890-1911 yılları arasında hükümet toplam 270 maden çıarma yetkisi vermiş bunun 102'si Türklere, 101'i yabancılara ve 67 'sinin de azınlıklara verildiği bilinmektedir. Ancak toplamda Cumhuriyet öncesi sektörde yerli sermayenin payının azalarak devam etmiş olduğu ve Türklere ilişkin destekleme politikalarının üretime 
yansımasının başarısız olduğu söylenebilir (Kepenek ve Yentürk, 2011:15). Osmanlı döneminin sonlarında madencilik üretimi önemli ölçüde artmıştır. Madencilik alanında, daha çok yabancı ve azınlık sermayesi egemendir. Osmanlı yönetiminin madencilik konusundaki getirdiği düzenlemeler, sürekli olarak yabancı sermayenin yararına olmuştur. Hükümetin yerli sermayeyi destekleme, maden gelirlerini vergileme ve maden dışsatımını sıfırlama doğrultusundaki girişimleri genel olarak başarısız olmuştur (Kepenek ve Yentürk, 2011:16).

Cumhuriyet dönemine gelindiğinde ise madencilik konusunda göreli olarak daha fazla önem verildiğini söylemek yanlış olmaz. Cumhuriyet'in kuruluş dönemlerinde kısmen liberal politikalar uygulanmak istense de yeterli girişimci ve sermaye olmadığı için sanayileşme ve kalkınma faaliyetlerini esas olarak devlet üstlenmiştir. 1930 yılından sonra tüm dünyada, devletçi, müdahaleci ve korumacı politikalara yönelinmeye başlanmıştır. Türkiye de bu doğrultuda hareket ederek, bunalımdan çıkmak ve iktisadi genişlemeyi sağlamak amacıyla çeşitli tedbirler almıştır. Bu kapsamda madencilik devlet korumasına alınmış ve milli sanayileşme çalışmalarının merkezine oturtulmuştur. 1935 yılında, maden arama faaliyetinin pahalı ve riskli bir iş olduğu, bu nedenle özel sermayenin çekingen davrandığı, ancak, memlekette yeni maden yataklarının aranıp bulunma zarureti olduğu gerekçesiyle Maden Tetkik Arama Enstitüsü ve bu kurumun bulacağ1 madenleri işletmek üzere Etibank kurulmuştur (Makal, 1999: 241). Böylece, devlet, madencilik alanına yatırımcı ve işletmeci olarak girmiştir. Bu alandaki kamu faaliyetleri iki yönde yürütülmüştür: önce taşkömürü ve bakır madenlerinin işletme yetkisi, sirasiyla Fransiz ve Alman ortaklarından, 1936'da satın alınmıştır. Sonra da kamulaştırmalarla birlikte, krom ve demir başta olmak üzere, madenlerle ilgili üretim ve arama çalışmaları yaygınlaştırılmıştır (Kepenek ve Yentürk, 2011:75).

Madencilik doğal kaynakların en önemli bölümünü oluşturduğundan, planlı dönemde, enerji de 1970'li y1llarda dünyada görülen ve ülkemize de yansıyan petrol bunalımı ve ona bağlı gelişmelerin bir sonucu olarak, bu dönemden sonra önem kazanmıştır. Maden sektöründe üretim, 1970'li y1llarda oldukça sabit kalmış, 1980'li yılların ikinci yarısında önemli bir artış gerçekleşmiş, daha sonraki yıllarda ise durağan bir çizgi izlemiştir.

1980 öncesinde maden üretimiyle ilgili olarak mülkiyet tartışmaları öne çıkmış, doğal kaynakların mülkiyetinin topluma-devlete ait olup olmadığı yasalarla belirlenmeye çalışılmıştır. Bu konudaki tartışmalar 1978 yılında çıarılan bir yasa ile uygun görülen kimi maden işletmelerinin kamulaştırılması yoluna gidilmiştir. Böylece maden işletmelerinin kamu-özel ya da karma yapısı 1980 yılından sonra da sürmeye devam etmiştir. 1990'lı yıllarda kamu kesiminde maden sektöründe yapılan yatırımlarda keskin bir azalış olmuştur. 2000'li yıllardaki kriz madencilik üretiminde bir azalmaya neden olmuştur. 2003 yılı itibari ile de birçok kamu madencilik sektörü özelleştirme kapsamına alınmıştır. Özel kesim sektördeki birçok işletmeyi daha karlı çalıştırmaya başlamıştır. Öte yandan, kamu sektörünün sermaye yoğunluğu ve göreli olarak teknolojik üstünlügünden bahsetmek mümkündür. Ancak kamu kesiminde işyeri başına işçi sayısının yüksek oluşunun etkin bir üretim için gerekli olandan fazla ve verimsiz olduğu söylemi tartışmalı olmakla birlikte öne çıkmaya başlamıştır (Kepenek ve Yentürk, 2011:439-41). Böylece günümüzde, madencilik sektöründe öne çıkan söylem "kamu madencilik kuruluşlarının özelleştirilmesi" şeklinde olmuştur (Tamzok 2003:3).

\section{Madencilik üzerine yapılmış çalışmalar ve işin sosyal nitelikleri}

Madencilik işinin ürettiği işlerin kendine özgü ve oldukça ayırt edici bazı temel özelliklerinin olması özelleştirmenin etkilerini anlayabilmek açısından önemlidir. Madencilik alanındaki çalışmaların hemen bütünü kırsal yörelerde yer almaktadır. İşletilecek kaynağın taşınması, işletmenin başka bir yerde kurulması olanaksızdır. Bu nedenle, istihdam edilecek işçilerin bütünü ya da büyük bölümü çevreden, köylerden sağlanır. Maden 
Mühendisleri Odası Madencilik Sektörü ve Politikaları raporunda (2011) değinilen diğer ayırt edici niteliklerini şöyle özetlemek mümkün gözükmektedir.

- Üretildiğinde yerine konulamayan tükenen varlıklardır.

- Her aşaması çok risklidir.

- Yatırımin geri dönüş süreci uzundur.

- Yer seçim şansı yoktur, bulunduğu yerde işletilmesi zorunludur.

- İstihdam ve katma değer yaratan emek yoğun bir sektördür.

- Çevreye etkisi önlenebilen veya kontrol edilebilen bir sektördür.

- Genellikle kırsal kesimlerde yapıldığından iç göçü önler.

- Madencilik yapılan bölgeler daha hızlı kalkınır.

- Ekonomik kalkınma için madenlerin planlı bir şekilde üretilmesi gereklidir.

- Krizlerden en çok etkilenen sektörlerden birisidir.

- Madencilik faaliyetleri durdurulduğunda yeniden üretime alınması büyük maliyetlere neden olmaktadır.

$\mathrm{Bu}$ temel nitelikler iş ve yerleşim yeri arasında özel bir etkileşim geliştirmekte ve işe bağlı sosyo-kültürel etkiler üreterek madencilik işini ve bu işte çalışanları özel bir topluluk haline getirmektedir (Dennis ve diğerleri, 1956; Bulmer, 1975). İş ve yerleşim yeri arasındaki özel bağın ürettiği homojen cemaatler uzun yıllar sosyal bilimler açısından doğal bir sosyal laboratuar işlevi görmüştür (Ackers ve Payne, 2002: 184; Kıray, 1964). Madenciliğe bağl1 topluluklarda, işçi sınıfının doğası, sınıf çatışmaları, modernleşme, emek hareketleri, siyaset, din, aile yapıs1, toplumsal cinsiyet gibi konular sosyal bilimlerin farklı disiplinleri tarafından çalışma konusu yapılmıştır. Kömür madenleri ve maden çevresinde oluşan yaşamı inceleyen ilk çalışmalar 1950'lerle başlamıştır. Dennis ve arkadaşlarının 1956 yılında yapmış oldukları "kömür bizim hayatımız" çalışması, madenciliğe bağlı işçi sınıfının oluşturduğu topluluğu anlamada önemli bir çalışma olarak ele alınabilir. Çalışma, bir endüstri olarak madenciliği çalışmanın ötesinde kültürel, sosyal ve ekonomik etkilerini anlamaya çalışan ve bir maden kasabasinda (Featherstone) yaşamanın nasıl olduğunu gösteren antropolojik bir çalışmadır. Bu kapsamda maden endüstrisinin ürettiği yaşamın temel esaslarını; düzenlilik, belirlilik, yakın dayanışma, ayrışmış kadın erkek rolleri, güçlü sendika, güçlü çekirdek aile üreten yapısına değinilmiştir. 2000 yılında Royce Turner aynı maden kasabasına tekrar giderek gerileyen kömür endüstrisinin ne tür değişimlere yol açtığını çalışmıştır. "Kömür hayatımızdı" isimli çalı̧̧ma ile belirsizlik, güvensizlik, zayıflayan dayanışma, parçalanan çekirdek aile, artan suç ve gençlerde yarattığı amaçsızlık gibi sonuçlar ürettiğini tespit etmiştir.

1960'lı yıllarla birlikte kömür madenlerine dayalı topluluklar, sinıf yapisinda meydana gelen değişimleri görebilmek için yeniden çalışılmaya başlanmıştır. Kömür madenlerinde çalışanlar ile bunların oluşturdukları yerleşim alanlarının homojen/birbirine benzer özellik ürettiği veri kabul edilerek yeni sanayinin kentsel alanlarda oluşturmaya başladığı görece daha zengin/varlıklı, mekân açısından daha bireyselleşmiş oluşumları değerlendirebilmek amacı ile adeta bir referans noktası olarak ele alınmıştır. Böylece kömür madenleri ve onun ürettiği topluluklar sinıf-meslek-mekân çerçevesinde değerlendirilmiştir (Strangleman, 2001:254). Daha sonraları ise endüstri-topluluk arasinda kurulan sinif-mekân-meslek üzerinden yapılan çalışmalar kritik edilmeye başlanmıştır. Örneğin Peter Ackers 1996'da yapmış olduğu çalışmada, daha evvel yapılan çalışmaların "romantik tarihçilik" olduğunu bu üçleme ile kömür madenlerinde çalışanlara ilişkin "stereotip madenci" ürettiğini ve aslında üretilen bu ideal tipin de gerçekte olmadığına dikkat çekmiştir. Genel olarak üretilen bu ideal tipleme ise şöyledir: "mekânsal olarak izole, madenin hakim olduğu ekonomi, birbirine sıkı bağlı sosyal ilişkiler, paylaşılan bir topluluk bilinci ve oldukça farklılaşmış toplumsal cinsiyet rolleri" ile karakterizedir (Bulmer, 1978). Böylece 
zamana ve yere bağlı olarak kömür madenlerinin oluşturduğu topluluklarda -hem aynı toplulukta hem de topluluklar arasındafarklılaşmaların olduğu üzerine odaklanan çalışmalar ortaya çımaya başlamıştır. Örneğin Williamson'un 1982 yılında yapmış olduğu "sınıf, kültür ve topluluk" çalışması "madencilikte sosyal değişim" üzerine odaklanmaktadır. Bu çalışma; ulusal ve yerel dinamiklerde meydana gelen değişimlerin maden topluluklarını nasıl etkilemekte olduğunu otobiyografik deneyimlerle tartışmıştır. Bugün bu boyutlara küresel değişimi de eklemek gerekmektedir. Özellikle yeni enerji kaynaklarının yaygınlaşması, teknolojik değişiklikler sektörü ve sektörde yer alanların hayatını değiştirmekte ve artık 'değişim' daha belirleyici olmaktadır. Değişimi görebilmek için farklı bölgelerde bulunan maden ocakları ve bağlı sosyal yapıları incelemek mümkün iken aynı toplumsal yapıya tarihsel bakış da değişimi yakalamak ve göstermek için kullanılabilmektedir (Richard, 1996; Simpson, 1988).

Aile, akrabalık; arkadaşlık ve yerellik üzerine oturan sosyal ağların incelenmesi değişim ve değişimin etkilerini görebilmek için önemli bir yaklaşım sunmaktadır. Ayrıca böylesi topluluklarda oluşan "birlik" hissi oldukça kaygan bir zemin sunmakta, topluluğu bir arada tutan şeyler önemli olduğu kadar topluluğun neleri dışladığı/dışarıda bıraktığını anlamak da aynı derecede önemli olabilmektedir. Yine maden topluluklarını anlamak için Roberts'un (1993) geliştirdiği kavram 'beklenti sosyalizasyonu/anticipatory socialization' önemli olmaktadır. Genel olarak madenin olduğu alanlarda madenin ana iş olması, yeni nesilleri de madene bağımlı kılmaktadır. Bu durum, dede, baba, oğul gibi üç kuşak hatta dört kuşak maden işçisi üretebilmektedir. Yaşanılan çevrede yapılabilecek işlerin sınırlı olması önemli bir neden olabilmektedir. Kırsal alanda yaşayan nüfusun eğitim olanaklarına ulaşımlarının sınırlı olması, onları genellikle düşük eğitimli ve düşük becerili gruplar haline getirmekte ve böylece göç etme şanslarını da azaltmaktadır. Sonuç olarak madende bir iş sahibi olmak en önemli amaç ve zorunluluk haline gelmektedir. $\mathrm{Bu}$ zorunluluk kırsal nüfusu madene bağımlı hale getirmektedir. Böylece mesleki kimlik, toplumsal kimlik, norm ve değerler işyeri ve işyerinin içinde yer aldığ 1 toplumsal alanda üretilmekte ve yeniden üretilmektedir.

\section{Tunçbilek Kömür İşletmeleri}

Madencilik işine dair bazı temel nitelikler belirlemek mümkün gözükmektedir. Çalışma açısından önemli olan niteliklerden biri madenciliğin genel olarak kırsal bölgelerde yapılmakta olduğudur. Daha doğrusu maden nerede ise sektör orada olmaktadır. Bu anlamda "taşınmazlı̆̆ı" söz konusudur. Temel olarak madenin bulunması ile sektörün oluşması ve madene bağlı sosyal yaşamın gelişmesi madenin nerede yerleşik olduğu ile yakından ilişkilidir. Maden belirli bir yerleşimin olduğu bir alanda olabileceği gibi madenin bulunmasına bağlı olarak kendi topluluğunu da üretebilmektedir. Bu anlamda Tunçbilek kömür madeni bulunduğu vakit bu belde ve civar köylerinde yaşamakta olan insanların olması burayı madenle "oluşan" değil maden ile "değişen" bir topluluk olarak ele alınmasını gerektirmektedir. Bölgede maden bulunmadan önce bir yaşam olduğundan madenle birlikte insanların yaşamları değişmeye başlamış, ücretli işçilikle tanışılmış ve yapılan temel faaliyetler ve geçimin biçimi değişmeye başlamamıştır. Geleneksel yaşam biçiminden ücretli işçiliğe geçmek hele madencilik gibi zor, tehlikeli bir işe başlamak başlangıçta zor olmuştur. Ancak geçen zamana bağlı olarak ve madenin yarattığ1 çevresel etkilerle birlikte geleneksel geçim biçimleri gerilemeye başlamıştır.

Tavşanlı-Tunçbilek'te Türkiye Kömür İşletmeleri Kurumu Garp Linyitleri İşletmesi Bölge Müdürlügü'ne (TKİ-GLİ) ait linyit sahalarında 1940 yılından bu yana kömür üretimi yapılmakta olup enerji gereksinimi nedeniyle 1980 'lerde üretim artırılmıştır. Günümüzde bu faaliyet $460 \mathrm{~km} 2$ bir alanda devam etmektedir. Üretim kapalı ve açık ocak yöntemiyle sürdürülmektedir. Kasım 2001 ve Şubat 2002 krizleriyle birlikte GLİ'den yoğun bir resen emeklilik süreci başlatılmış olduğundan işçi sayısı bugün itibariyle 3500 
civarındadır. Bugün Türkiye'nin enerji ihtiyacının yaklaşık \%23'u kömürden karşılanmakta olup, linyite dayalı elektrik santrallerinde yerli kaynakların pay $\% 15^{\prime}$ tir.

Tunçbilek linyit üretim havzasında yer alan Beke, Ömerler, Bozbelen, Demirbilek köyleri ve Gürağaç Beldesi'nde kömür üretimi ve dekapajdan dolayı toprak kaynakları kullanılamaz hale gelmiştir. Verimli topraklar ve ormanlık alanlar kamulaştırma nedeniyle giderek küçülmüştür. Yamaçlardan dökülen atık toprak, orman üzerinde ciddi tahribat yaratmıştır. Köylerde tarım ve hayvancılık uğraşı bitme noktasına gelirken, tarımsal üretimden kopan insanların maden işletmesinde istihdam edilmemesi/edilememesi nedeniyle de işsizlik artmıştır. Ayrıca Tavşanlı-Tunçbilek linyit üretim havzasında madencilik sosyal ve ekonomik yönden insanları etkilemiş, sağlıkla ilgili sorunlara yol açmış, çevre ve güvenlik sorunları (atıklar, su ve hava kirliği, toprak kayması vb.) yaratmıştır (Dersan ve Tuğrul, 2004). Bu süreçte yenilenebilir kaynaklar; ormansızlaşma, erozyon, toprak kalitesinin bozulması, biyolojik çeşitliliğin kaybı, su akışlarının bozulması, mera kaynaklarının yok olması, yaban çeşitliliğinin azalması vb. etkilerle tahrip olmuştur. Madencilik alanında yaşayan insanlar, kamulaştırma yoluyla, yerleşim yerlerini, tarım arazilerini, meralarını, ormanlarını vb. geçim kaynaklarını kaybetmiş ve madene bağımlılıkları artmıştır. Ayrıca teknolojide meydana gelen değişim de işçi gereksinimini azaltmıştır.

\section{5. Çalışmanın Metodu:}

Bu çalışma 1940'l1 yillardan bu yana Tunçbilek ve ona bağlı köylerde yaşayan insanların hayatını derinden etkileyen kömür maden işletmeleri ve bu işletmelerde meydana gelen değişimlerin çalışanlar üzerine olan etkilerini incelemektedir. 1940'lardan 2000'li y1llara kadar Tunçbilek Kömür Madenlerin işletmesi devlet eliyle yürütülmüş ve madende çalışanlar devlet işçisi olmuştur. Ancak 2000'li yıllarla başlayan özelleştirme ile birlikte özel sektörün işletmekte olduğu maden işletmelerinde çalışmakta olan işçi sayısı artmaya başlamıştır. Maden işçiliği Tunçbilek ve civar köylerde yaşayanlar için dördüncü kuşağını üretmiş bir iştir ve ailelerin yaşamı, gündelik yaşamın üretilişi bu iş etrafında örgütlenmektedir. $\mathrm{Bu}$ çalışmada değişen maden işçiliği; iş/meslek, sosyal yaşam ve ileriye yönelik sosyalleşme açlarından incelenmiştir. Çalışma bir yönü ile Tunçbilek kömür madeninde meydana gelen değişimleri tarihsel olarak değerlendirmekte diğer yandan ulusal ve küresel değişimlerin maden işi üzerine etkilerini ele almaktadır. Bu amaçla 40 maden işçisi ile derinlemesine görüşme tekniğ $i$ kullanılarak görüşmeler yapılmıştır. Görüşmeler, görüşülen kişilerin izni alınarak kayıt edilmiştir. Çalışmanın saha aşaması Haziran 2011 tarihinde gerçekleştirilmiştir.

\section{Bulgular ve Tartışma:}

Çalışmanın bulguları iki dönemleştirme yapılarak ele alınacaktır. Birinci dönem devletçi ve korumacı dönemin etkileri, ikinci dönem ise özelleştirmeye bağlı deneyimlenen değişimleri ele almaktadır. Dönemleştirmeler ele alınırken, madencilik işinin temel nitelikleri, sendika, aile ilişkileri, iş-mekân birlikteliği-ayrılığı gibi alt başlıklarla ele alınacaktır.

\subsection{Korumacı ve devletçi dönemde madencilik işi}

\subsubsection{Maden işçisi olma ve işe başlama}

Madencilik sektörünün tüm emek tarihi çalışmaları açısından özel bir önemi vardır. Bunun nedeni, madencilik ve özellikle de kömür madenciliği faaliyet alanının tarih boyunca işçilerin çalışma koşullarının en kötü olduğu ve uzun yüzyıllar süren mücadelelere sahne olan bir kesim olmasıdır. Nitekim yeryüzü ölçeğinde ilk sosyal politika tedbirleri de madencilik sektöründen başlayarak gerçekleştirilmiştir. Madencilikteki çalışma koşullarının diğer kesimlerden daha güç olması emek arzının yeterli olmamasına yol açmıştır. Madenciliğin özellikle savaş yıllarında stratejik önemde olması ve savaş nedeni ile üretimi arttırma çabalarına bağlı olarak fazla çalıştırma uygulamaları nedeni ile başlangıçta yerli halk tarafından pek de çalışılmak istenmeyen bir iş olarak görülmüştür. 1940'l1 yıllarda Tunçbilek Kömür İşletmelerinde ilk çalışmaya başlayanlar 
zorunlu çalıştırma kapsamında çalışmaya başlamışlardır. Bazı görüşmeciler dedelerinden dinledikleri geçmiş hafızayı bilmektedirler.

“Dedem mükellefmiş, askerliği
işletmede yapmış. Önceden orada
çalıştıracak eleman bulamadıkları için
devletle herhalde anlaşma yapmışar.
Demişler ki, iki sene mi ne askerlik,
sonradan iki senesini de burada
yeraltında çalışmış. 'Biz kaçardık'
diyor, sonradan jandarma gelirmiş
'hadi bakalım işe' diye zorla
çalıştırırmış..." (34 yaşında, lise
mezunu, 7 yıldır açlk madende işçi,
Tavşanlı).

Mükellefiyet yasasının 1946 yılında kaldırılması ve arzu edilen sonuçları sağlayamaması nedenleri ile ortaya çıkan işgücü açığı mahkûm işçilerle giderilmeye çalışılmıştır. Mahkûmlara ilave olarak askerler de çalıştırılmıştır. Askerlik teciline ve/veya askerlik muafiyetine dayalı mükellefiyet uygulaması ile ücret ödemesi de yapılmıştır (Makal, 2004:123). Mahkûm ve asker çalıştırma, sektörün iş örgütlenmesini çok belirlemiş gözükmektedir. Madencilikte kullanılan terimler askeri terimlerdir. "Çavuş", "başçavuş", "operasyon" gibi terimler kullanılmakta ve ast-üst ilişkileri de bu hiyerarşiye benzemektedir.

1950'lerle birlikte zorunlu çalıştırma uygulamasının yerini gönüllü işçilik almıştır. Aslında buradaki gönüllülük bir miktar zorunluluk kaynaklı olmuştur da denilebilir. Özellikle maden sahası içinde kalan toprakların kamulaştırılması ile temel geçim kaynaklarını kaybeden köylü gruplar için madende işçileşmek dışında pek seçenek kalmamıştır. 1980'li yıllara kadar sürekli gelişen maden ve termik santrali faaliyetlerine bağlı olarak işçileşme hız kazanmıştır. 194090'lı yıllar dikkate alındığında madende işçileşmenin kolay olduğu, toprakları kamulaştırılan işçilerin madende çalışma haklarının olması, Tunçbilek ocaklarında çalışacak işçinin civar köylerden karşılanması küçük tanışıklıklar sayesinde iş başı yapabilme olanağı sunmuştur.

\subsubsection{Aile-Yakın Sosyal Çevre İlişkisi}

Tunçbilek Kömür İşletmelerinin devlet eliyle yürütülmesi, kamulaştırmanın devlet aracılığ ile yapılması ve kamulaştırma yapılan topraklarda yaşayanların mağdur edilmeden kömür işçisine dönüştürülmesi ve zaman içinde madende işçi olmanın avantajlarının daha fazla olması nedenleri ile Tunçbilek gelişmeye başlamış ve gelişme daha ziyade yakın çevre köylerinden insanların kamulaştırmalar aracılığ 1 ile işçileşmesine bağlı olmuştur. Bu süreçte başka yerlerde kapanan, biten ve devlet eliyle yürütülmekte olan madenlerde çalışan bazı devlet işçileri Tunçbileğe gelmiştir ancak o zamanlar maden büyüme evresinde olduğundan ve yerli halkın hak kaybı olmadığından isteyen herkes madende iş bulabildiğinden dışarıdan gelenler memnuniyetle karşılanmıştır. O vakitler (197090 yılları arası) yaklaşık 12 bin kişi madende çalışmaktadır ve Tunçbilek pek çok sosyal olanakları ile renkli bir cazibe merkezi niteliğindedir.

Bir ideal tip olarak madencilik işi; fiziksel izolasyona dayalı, madenin hakim olduğu ekonomik yaşam, yakın sosyal ilişkiler ve oldukça farklılaşmış toplumsal cinsiyet rolleri ile karakterize edilebilir gözükmektedir (Bulmer, 1975). Maden alanlarının genel olarak kırsal alanlar olması ve/veya maden nedeni ile yarattığı özel durum nedeni ile madencilik erkeklerin yaptığı, kırsal niteliği gereği ile de tek gelirli aile yaratan bir iştir. Madencilikle birlikte tarım ve hayvancılığın gerilemesi, ücretli işçiliğin daha cazip olması, tüm tehlikelerine rağmen genel olarak en azından başlangıcından son yıllara kadar "iyi ücretli" iş olması gibi nedenlerle tek gelirli aile üretmektedir. Bu nedenle tüm ailenin yaşam standardı erkeğin işine ve iş güvenliğine bağlıdır. Bu nedenle madencilerin ifadesi ile madencinin karısı da "madencidir". Madende meydana gelebilecek her türlü olumsuzluktan eş ve çocukların direkt etkileniyor olması eşleri etkilemektedir. Yine maden işinin vardiyalı olmas1, madencinin iyi beslenmesi ve 
dinlenmesi gerektiği gerçeği madenci eşlerini de madenci gibi yaşamaya itmektedir. Erkeğin mesaisine göre ev yaşamı düzenlenmekte, madencinin iyi beslenmesi, dinlenmesi ve aile meselelerine kafa yormaması gerektiği belirtilmektedir. Madencinin tüm dikkatini işine verebilmesi ve olası tehlikelerden kendini koruyabilmesi için "düzenli bir aile yaşamı" şarttır. Bunu bütün maden işçileri tekrarlamaktadır. $\mathrm{Bu}$ nedenle eşler hatta çocuklar da işin parçası haline gelmektedir.

“Hemen kafasını koyar, yatardı. Öyle kendi kalkmadıktan sonra ben akşama kadar kaldırmazdım eşimi. Çünkü sabaha kadar ayakta. Yorucu. Burada iş buyuramazdım ben. Şurada yapamayacağım işi bile yap diyemezdim. Çekiniyor insan. Devamlı çalışıyor. Hep, 'siz benim çalıştığım yeri görseniz bir dilim ekmeği oturup rahat yemezsiniz' derdi. E biliyorum orada hayatın zor olduğunu biliyoruz. Gitmedik, görmedik ama o elbiselerinin halinden bilirdik. O sslak gelirdi gün olurdu elbiseleri" (50 yaşında, ilkokul mezunu, kadın, eşi 27 yıl madende yer altı/ustu çalışmış 1 ay önce emekli olmuş, Tavşanl1).

\subsubsection{Sendika ve Birliktelik Deneyimi}

Türkiye sendika tarihinin en eski sendikalarından olan Maden İş sektördeki sendikadır. Sektörün başından beri sendikanın olması, özellikle orta yaş ve üstü işçiler için çok anlamlıdır. Sektörde yıllar içinde artan devlet kadrosunda çalışan işçi sayısına bağlı olarak güçlü bir sendika ve işçi örgütlülüğü deneyimlenmiştir. Kuruluşundan bu yana uzlaşmacı ve işlevsel bir sendikacılık benimsenmiştir. İşçilerin anlatılarında özellikle iş güvencesi konusundaki sendika çalışmaları ve işçiyi korumaya yönelik faaliyetleri takdirle karşılanmaktadır. Ayrıca işçiyi yalnız bırakmaması, işçinin yanında olması ve işçi haklarını koruması açısından da çok önemsenmektedir. Kamuda çalışan işçiler için sendika ve sendikalı olmak oldukça önemli görülmektedir.

"Sendika benim avukatım, savunucum her şeyim. İşyerinde bazı haksızlıklar oluyor. Bunu ben kendi başıma savunmaya kalktım $\mathrm{m}$ işveren benim çalışma hakkımı feshetmeye kadar gidiyor. Ama sendikam benim için beni savunur" (50 yaşında, 26 yıldır madende çalışıyor, endüstri meslek lisesi mezunu, Tavşanlı, evli).

1960-90 yılları arası Tunçbilek tam bir maden kasabası nitelikleri barındıran, sosyal açıdan zengin, herkesin madende işçi olduğu yaşamın madenciliğe bağlı şekillendiği yıllardır. O yıllarda çalışanlar özellikle beyaz yakalı çalışanlar için yapılan lojmanlar, beyaz yakalıların ailece gelip burada yaşamaları hayatı zenginleştirmiştir. Yaklaşı 10-15 bin çalışanı ile önemli bir sosyal yaşam üretmiştir. Madenciler için lokaller, lojmanlar, kooperatifler, özel geceler, bando, koro, sinemalar, yüzme havuzları, özel eğlence geceleri ile oldukça zengin bir yaşam alanı üretmiştir.

"Zamaninda bundan 15-20 sene önce 3 tane sinemamiz vardı bizim Tunçbilek'te. Nasıl diyeyim. Kütahya'da yokken bizim Tunçbilek'te vard1. 2 tane yüzme havuzumuz vard1. Lokallerimiz vardı. Bu sosyal hayat madenciler gecesi veda geceleri...Çok aktifti. O mesela bizim Linyit Spor. Bunlar bizim hep Tunçbilek'ten çıtıtı. Şimdi iyiyken herkes sahipleniyor. Benim en çok zoruma giden nokta da bu. O madenciler mahallesinde yıkılan yerde eskiden 1000-1500 kişi yaşıyordu. Orada lokaller vardı. Madenci kooperatifleri vardı. Çalışan insanlar oralara alışverişe giderlerdi" (50 yaşında, 26 yıldır madende çalışıyor, endüstri meslek lisesi, Tavşanlı, evli). 
Tunçbileğin 12 bin işçi ile çalıştı̆̆ 1 dönemler, o vakit ilçenin sosyal yapısı ve olanakları, güçlü sendika, canlı sosyal hayat, iyi ücretler ve sosyal hakların olduğu geçmiş günler "efsane" olarak hatırlanmaktadır.

Bir yandan maden diğer yandan termik santralinin olması başka sektörlerin gelişmesine engel olmuştur. Her iki sektörün dışında gelişmiş başka sektör yoktur, servis sektörü de gelişen sektördür ama bu iki sektöre bağımlı durumdadır. Bu sektörlerin gerilemesi doğal olarak servis sektörünü de geriletmektedir.

“49'da işletme kurulmuş. 1960-65 gibi termik kurulmuş. Bunlar var diye her hangi bir yatırım yapılmamıs buraya. Gelen oraya gireriz, burada iş yaparız. Ondan sonra esnaf kesimi, işletmeyi afedersin sağılacak inek gibi görmüşler. 'Oradan gelir, biz kendimizi geçindiririz' gibisinden. Onlar da öyle bir yatırım yapmadılar. E ne oldu? Bu duruma geldik. Şu anda tıkandık yani" (55 yaşında, 27 yıldır madende çalışıor, sanat okulu mezunu, makine bakım-tamircisi, Tavşanl1).

\subsubsection{Madencilik İşi ve İşçiliği:}

Madencilik zor, riskli, bedensel güçle yapıldığ1 için yaş seçen bir iştir. Yani yaşlandıkça yapılması güçleşmektedir. İşin kendine özgü, deneyimle kazanılan nitelikleri vardır ama başlangıç olarak yani kimler madende çalışmaya başlar, kimler madenci olur sorusunun genel olarak olumsuz içerikte algılandığ1 görülmüştür. Bunun temel nedeni işin risklerine ilişkindir. Tehlikeli bir iş olması, iş güvenliğine ilişkin tedbirlerin iyi alınmadığ 1 durumlarda sık kaza yaşanan bir iş kolu haline gelmektedir. Ayrıca kömür tozu, çalışma alanının bizatihi kendisi sağlık için olumsuz etkiler üretmektedir. Tüm riskler, tehlikeler ve güçlükleri nedeni ile "yapacak başka iş bulamayan insanların" madenci olduğu genel kanıdır.

\begin{abstract}
“Bir kere beden gücünün yanında kafanın da çalışması lazım. Beden gücü birinci şart. Bir de kafanın da çalışması lazım. Neyin nerden geleceğini, tehlikenin nereden geleceğini bilmen lazım. Ama genelde köylü kesim, ezik kesim, işsiz kesim madenci olur" (36 yaşında, lise mezunu, yer altında çalışıyor, şirket işçisi, Tavşanlı, evli).
\end{abstract}

Yer altı ve yer üstü ayrımı önemli bir ayrımdır. Genel olarak özellikle genç yaştakiler için yeraltında çalışmak tercih edilmektedir. Ağır iş kategorisinde olduğu için daha erken emeklilik olanağı sunuyor olması tercihin en önemli nedenidir. Özellikle son yıllarda yükselme eğiliminde olan emeklilik yaşı, genç işçileri hiçbir zaman emekli olamayacakları hissiyatına sokmaktadır. Bu nedenle tehlikeli, zor ve yorucu olsa da yer altı çalışması istenmektedir. Yer altı, belirli bir süre sonra tecrübe kazanılmasına bağlı olarak alışılan ve "yerüstünden" farksız hale gelen bir çalışma yeridir. Ancak yeraltında çalışırken sigara içememek, sicak yemek yiyememek ve uyuma gibi riskleri barındırmaktadır. Ayrıca göçük, patlama, hava ve basınç farklılıklarının yarattığı olumsuz koşullar da çalışanı olumsuz etkilemektedir. Ayrıca çok izole bir çalışma ortamının olması, yenilikleri öğrenme, yapılan işte yükselme şanslarının azlığı da diğer olumsuzluklardır.

“Tabi, fabrikayı tercih ederdim. Mesela daha açık, orada bir şeyler öğrenmeye imkan var. Burada neyi öğrenebilirsin yer altında? Kazma-kürek yani, bunu siz de yapabilirsiniz misal. Hani çok özel bir şey değil. Yeraltında bir şey öğrenemezsin fazla. Yükselemezsin" (57 yaşında, devlet işçisi olarak emekli, Tunçbilek).

Ancak birlikte çalışan iş̧̧ilerin dayanışması, aynı zorluklar altında olmaları, yemeklerini birlikte yemeleri, birbirlerini kollamaları özel 
bir çalışma ortamı yaratmaktadır. Herhangi bir aksilik olması halinde yukardan birileri gelinceye kadar çok geç olacağının farkındadırlar. Bu nedenle uyumlu olmak, birlikte iyi anlaşmak ve birbirini kollamak önemli olmaktadır.

“Oradaki arkadaşlık daha fazladır. Dışarıdakinden çok daha fazladır. Çünkü burada girişte kavga edersin, yeraltında kazaya uğrarsın. Ben seni sırtımda dışarı taşırım. Veya sen beni sırtında taşırsın bir arkadaş olarak. Bu kadar bağlıdır. İhtiyaçtır yani, mecburdur yani. Kaza olduğu zaman arkadaşın 'ben bununla sabah kavga ettim' diyemezsin. Aynı olay senin başına da gelebilir. Seni de biri sırtında taşımak zorundadır. Ona çok bağımlıdır" (57 yaşında, devlet işçisi olarak emekli, Tunçbilek).

İş kazasına uğramak, ölmek, sakat kalmak bir organını kaybetmek olasılık dahilindedir. Bu güçlükler bilindiği için de her gün evden çıkarken dönülüp dönülmeyeceğinin bilinmediği bir iştir. Ancak ilçenin temel iş alanı olduğu için çevre tarafından iyi bilinen, saygı duyulan "tam bir erkek işi" dir.

"Yukarı baksan ayağını makineye kaptırma ihtimali yüksek. Aşağ baksan kafana taş düşebilir. Dalgın olmayacaksın, uykusuz olmayacaksin. Bu madencilik uykusuzluğu götürmez. Yani sivil hayat ile maden hayatını ayıracaksın. İş yerine gittiğinde kendi kafandaki problemleri sileceksin. Maddi olur ailevi olur. Sıkıntıları bırakacaksın. İşe vereceksin kendini. Ama işin sorunlarını da eve taşımayacaksın. Yani ocaktan çıktın, her şey biter" (32 yaşında, 7 yıldır madende şirket işçisi, Tavşanll, lise mezunu, evli).

Ayrıca maden işinin düzenliliği, kolayca dahil olunabilmesi, görece iyi ücreti ve 'hak edilmiş kazanç' hissinin onaylanması nedenleri ile bu meslek/iş aktarımı devam etmektedir. Özellikle açık maden işletmeciliğinde kaldırılan toprağın maden alanı dışında biriktirilmesi, toprak göçmeleri ve ekolojik değişimlerin tümü tarım ve hayvancılık faaliyetlerinde gerileme yaşanmasına yol açmaktadır.

Tehlikeli ve zor bir iş olduğu çevre tarafından bilindiğinden işe verilen sosyal sayg1 yüksektir. Ayrıca yörede madenle rekabet edebilecek başka iş kolu da yoktur. Yöre dışına çıkmak da çok istenmemektedir. Düşük eğitimli ve düşük becerili gençler yöre dışında bulabilecekleri niteliksiz ve düşük ücretli işler için memleketlerinden ayrılmak istememekte ve bir yolunu bularak madene girmeyi denemektedirler. Maden rezervlerinin sonsuz olduğunu düşünmekte, bir gün bitebileceği ve işsiz kalacaklarını düşünmemektedirler. Ayrıca madende çalışmak "madenci" olmaya yani bir meslek sahibi olmayı sağlayacağı için de yakın çevrede başka madende çalışılabileceğine inanmaktadırlar.

“Güvenlik görevlisi olarak İstanbul'da çalıştım. İmkânlar kısıtlıydı. Koşulları zordu. 12 saat çalışıyordum. Onların koğuşları vardı. Orada kalıyordum. Affedersiniz, aynı ahır gibiydi. Üst katında halı yıkıyorlardı. Tavan rutubet oluyordu, yosun tutuyordu yukarısı. Sonra hasta oldum. O koşullarda çalışmak istemedim. Asgari ücretin de altındaydı parası. Mecbur bırakmak zorunda kaldım. İstanbul büyük şehir, aldığım maaş bana yetmiyordu. Artı aileme yük oluyordum. Ben de baktım gördüm, bıraktım" (25 yaşında, muhasebe mezunu, 3 yıldır yeraltında şirket işçisi olarak çalışıyor, tavşanlı, evli).

Uzun yıllar devlet eliyle yürütülmesi, çalışmaya başlayanlar için zaman içinde çeşitli olanaklar sunması da işi devam ettirmek istemenin önemli bir nedenidir. Sendikadan, partiden, yörenin ileri gelenlerinden bir 
yakın/tanıdık bulmak ve bu tanıdığın desteği ile zaman içinde daha rahat çalışma olanaklarına kavuşmak olasıdır. Bu nedenle ücreti, koşulları ne olursa olsun önce madene girmek önemlidir. Zaman içinde deneyimli işçi olmaya ve genişleyen sosyal ilişki ağlarına bağlı olarak daha iyi koşullara ulaşıldığını görmüşlerdir.

\subsection{0'li Yıllar ve Özelleştirmenin Etkileri}

\subsubsection{Değişen madencilik işi ve teknoloji}

"İnsanlar o zaman için tarımla uğraşıyormuş belli geçim kaynakları varmış. İşçi bulamıyorlarmış. Dolayısıyla mahkûmları getiriyorlarmış buraya. Türküler yazılmış. Şimdi insanlara, normal askerden gelmiş bir gence 'Kardeşim 50 milyar para getir işletmede iş başı yap' deseniz kesinlikle verir ve dört gözle işe başlar. Şimdi bizim bu Kütahya bölgesinde büyük bir gelişmiş bir organize sanayi yok. Bütün işler iptal. Kütahya' da Termik santralimiz var. Azot fabrikamız vardı, şeker fabrikalarımız vardı bunların hepsi gitti" (35 yaşında, lise mezunu, kapalı madende elektrik işçisi, Tavşanlı, evli).

Madencilik özellikle yer altı madenciliği değişmekte, modernleşmektedir. 1996 yılında Çin'den gelmiş olan "mekanize" denilen sistemle birlikte madencilik değişmiştir. İnsan emeğine daha az gereksinim duyan teknoloji ile birlikte işçi sayısı da azalmaya başlamıştır. Eskiden olan kazma ile maden kazma artık değişmiştir. Yer altında çalışmaya bağlı olarak pek çok risk halen devam etmekle birlikte artık teknolojik üretim yapılmaktadır. Ancak madenciliğin temel kuralları değişmemiştir. Yer altında oksijenin az olması, göçük ve patlama riski her zaman vardır ama denetime ilişkin teknoloji de gelişmiştir.

“Daha önceden insan gücüyle, kömür madeninin çıkması insan gücüne dayalı idi. Şu anda insan gücü en asgaride, en az kullanılan sistem. Çin'den getirdiler, mekanize sistem getirdiler" (45 yaşında, meslek lisesi, yer altı devlet işçisi, 27 yıllık işçi, evli, Tavşanl1).

Özelleştirmenin artmakta olması madende temel olarak ikili bir yapı oluşturmuştur: devlet işçisi-şirket işçisi. Devlet işçisi, madende ilk çalışmaya başlayan grup olduğu için işi, işin risklerini, işe bağlı dayanışmayı, sendikayı ve iş çevresini çok iyi bilmektedir. Çalışmaya bağlı kazanımları yüksektir. Sendikal haklar konusunda iyi durumdadır. Madencilik işinin ağır koşullarına uygun olarak iyi ücretli olması, tehlikeli olması nedeniyle iyi tedbirlerin alınması ve düzenli denetlenmesi önemsenmiştir. Genel kanaate göre devlet için öncelik "güvenlik" ve "işçinin sağllğı" dır. Diğer yandan özel sektör için öncelik ise "kar" etmektir. Bu nedenle özel sektör maliyet arttırıcı yatırım ve tedbirlerden kaçınmaya çalışmakta ve aynı zamanda ücreti düşük tutmak istemektedir. Genel olarak sendikanın olmaması, işsizliğin yüksek olması gibi nedenlerle de şirkette çalışanlar örgütlü bir grup olamamaktadırlar.

\footnotetext{
“Özel sektör iş̧̧iyi sıkıştırıyor. Günde 3 metre istiyorum senden. Makine arıza yapiyor, bant arıza yapiyor. 3 metre istiyor. 8 saatte açmak zorundasin. Bu adam ne yapiyor? Tahkimatı belli bir standarda bağlamıyor. Bu bir risk işte. Hem kendi hayatı, hem arkadaşlarının hayatını riske atıyor" (32 yaşında, 3 yıldır şirkette çalışıyor, Zonguldak, evli, lise mezunu).
}

Özel sektörün istihdam ettiği yeni işçiler sayılan nedenlerle düşük ücretle, zor ve tehlikeli koşullarda çalışmaktadırlar. Şirket sadece işçisine değil madene de yeterli önemi vermemektedir. Kar mantığı ile kısa sürede en çok kömürü çıkarmayı hedeflediğinden madene, çevreye ve işçiye zarar vermektedir. Diğer yandan kısa dönemli bakınca şirket daha verimli gözükmektedir. Madenin devlet veya 
özel sektör eliyle işletilmesi arasındaki fark şu şekilde de kıyaslanmaktadır:

\begin{abstract}
“Öncellikli olarak eğitim. Devlet olduğu için iş güvenliğini daha çok alıyorlar. Devlet $50 \mathrm{~cm}$ 'de bir dayanak atarken, şirket 1 -1.5 metrede bir yapıyor. Boşluk kalıyor. İkincisi yan taraflarda bağları koyunca, taş oluyor kömür oluyor. Onların gelmemesi için ağaç parçaları, kama dediğimiz, koyuyorsun. Devlet daha sik koyarken, şirket daha aralıklı yapıyor" (25 yaşında, meslek lisesi muhasebe mezunu, 3 yıldır şirkette yer altı maden işçisi, evli, Tavşanlı).
\end{abstract}

Özel sektör çalışma barışını bozan etkiler de üretmektedir. Devlet işçisi ile şirket işçisi arasında kapanması imkânsız bir ayrışma yaşanmaktadır. Koşullarının daha iyi olması, sektörde eski oluşlarına bağlı daha bilgili ve deneyimli olmaları, sendikanın sağladığı koruyucu mekanizmalar ve sosyal haklar nedeni ile devlet işçisi olmak tercih nedenidir. Şirket işçileri tüm sayılan haklardan mahrum oldukları için kendilerinin haksızlığa uğradığını düşünmektedirler. Öte yandan, şirket işçileri şirketlerine tepki geliştirmek yerine sendikalı devlet işçilerine tepki geliştirmekte, onlara kızmakta ve kendilerinin hak kayıplarının nedeni olarak devlet işçilerini görmekte ve suçlamaktadırlar.

“Aldığınız ücrete bakarsan boş yani. Yer altında devletin işçisi 2.5 milyar maaş alıyor, benim 5 katım maaş alıyor. Ben onlardan daha fazla, yoğun çalışıyorum. Özel sektördeyim. O yerin altında 5-6 saat çalışır, çıkar. Ben 8 saati doldurmadan çıkamam. 8 saati doldurayım, geçiriyorum bile" (32 yaşında, 3 yıldır şirkette çalışıyor, Zonguldak, evli, lise mezunu).

Değişen teknoloji ve bunun işçilik üzerine etkileri özellikle eski işi ve çalışma koşullarını bilen işçiler tarafından değerlendirilebilmektedir. $2000 \quad$ sonrası madene işçi olarak girmiş olanlar mekanize sistemi bilmekte ancak önceki çalışma koşullarını bilmedikleri için değerlendirmeyi kendi deneyimlerinden yapmaktadırlar. 1984 yılında devlet işçisi olarak yer altı madencisi olarak çalışmaya başlayıp 2000 yılında emekli olan ve emekliliğin ardından özel şirkette baş çavuş olarak çalışma hayatını sürdüren Ahmet bunu şöyle açıklamaktadır: mekanize sistem, verimi arttırmakta, iş güvenliğini geliştirmektedir. Ancak mekanize sistem hem daha becerili işgücü talep etmekte ve hem de aynı zamanda da ücretleri düşürmektedir. İnsan emeğine olan gereksinimin azalması ücretlerin düşmesine yol açmaktadır.

\begin{abstract}
"Ama mekanize sistemde bizim gibi adamlara ihtiyaç yok, cahil olanlara... Ya elektrik ya mekanik sanat okulu mezunu olmak lazım. Yani kalifiye eleman. Onlara ihtiyaç duyuluyor. Üretim artırıyor. Tabi ücretlere gelince ücretler düşüyor"
\end{abstract}

Bölgede ve genelde ülkede işsizliğin yüksek olması da madende işçi olmak istemenin en önemli nedenidir. Madene girebilmek artık çeşitli sınavlara tabidir ve eskiden olduğu gibi tanıdıklar yeterli olmamaktadır. Eskiden madende çalışan birini tanımak işe girmekte önemli bir referans olmakta iken artık çok daha önemli kimselere ulaşmak, KPSS sınavından iyi not almak gerekmektedir.

Özel sektörde çalışan işçilere göre; devlet işçileri geniş haklara sahip olmalarına rağmen "tembeldir", "verimli çalışmamaktadır". Bu nedenle de devlet 'özelleştirme yoluna gitmektedir' gibi bir algı oluşmaktadır. Devlet işçileri daha iyi ve verimli çalışmış olsaydı devletin sektörde kalmaya devam edeceğini ancak böyle olmadığ 1 için kendilerinin olumsuz koşullara mahkûm olduğunu düşünmektedirler.

“Devlet bunu yapıyor. Özel sektörün eline geçerse ki geçiyor, işçi ezilir, 
iş̧̧inin sırtından birileri zengin olur. Aç millet ne yapsın çalışmayıp. Devlet kuzuyu kurdun ağzına atıyor" (50 yaşında, 25 yıldır yer altı işçisi, devlet işçisi, Ömerli, evli).

“Özelleştirme iyi bir şey olur mu? Çok kaza yapan oldu, kolu kopan, bacağ 1 kopan oldu. Zayiat çok fazla oldu. Şimdi devlette şu var, önce emniyet sonra iş. Özelde, önce iş sonra emniyet. Sonuçta para kazanmak için böyle yapıyor" (32 yaşında, 7 yıldır madende çalışıyor, şirket işçisi, lise mezunu, babası madenden emekli, evli, eşi çalışmıyor).

\subsection{2 İş güvenliği}

Maden işine ilişkin en önemli eğitim konusu "iş güvenliği" konusunda gerekli olmaktadır. Kamu bu anlamda iş güvenliğini önemsemekte ve uzun eğitimler vermektedir. Ancak özel sektör hemen iş başı yapmalarını istemekte, yaparak, bakarak öğrenme söz konusu olmaktadır.

"Şimdi taşeronlarda dediğim gibi iki günlük eğitim vardır, orda işte bu iş güvenliği eğitimi verilir, ilk yardım eğitimi alırsın. Kamuda çalışanları 1,5 2 aylık eğitimlerden sonra başlarlar. Diğer kurallar zamanla. Şimdi bu son kazalardan dolayı biraz daha işi sıkıya aldılar, eski çalışanlara bile eğitim veriyorlar yeniden" (32 yaşında, 7 yıldır madende çalışıyor, şirket işçisi, lise mezunu, babası madenden emekli, evli, eşi çalışmıyor).

Kamu işçisi olmak ile şirket işçisi olmak arasındaki farklar saymakla bitmemektedir. Ücret, çalışma koşulları, sendikal haklar ve sosyal haklar arasında uçurum vardır. Bazı şirket işçilerinin tanımlamaları ile 'şirket işçileri "köle" gibi sömürülmekte işin kaymağını ise "kamu" işçileri almaktadır':

\begin{abstract}
"Maddi olarak onlar ikramiye alıyor, kömür yardımı alıyor. Maaşları çok yüksek. Toplu sözleşmelere giriyorlar. Çalışma şartları bize göre biraz daha iyi. İște tazminat hakları olsun, her türlü hakları mevcut onların. Bizde şu an aylık maaş var, başka bir şey yok. İşte yemekten istifade ediyorsun, daha önce giyim kuşamı özel sektör karşıllyordu, onu da devlet kendi eli altına aldı ama kamu iş̧̧isiyle aynı haklardan yararlanamiyorsun" (32 yaşında, 7 yıldır madende çalışıyor, şirket işçisi, lise mezunu, babası madenden emekli, evli, eşi çalışmıyor).
\end{abstract}

Özel şirkette çalışan işçiler başka açılardan da kendilerini mağdur hissetmektedirler. Özellikle işten çıkarılmaları konusunda çok tedirgindirler. Zira işe girişte belirli formlar imzalatılmaktadır ve bu nedenle hak kayıpları yaşamaktadırlar. İşe girerken işe gereksinimleri olduğu için kendilerine sunulan her şeyi kabul ettiklerini ama daha sonra olumsuz bir durumla karşılaştıklarında başta imzalamış oldukları evrakların onları korumasız hale getirmekte olduğunu söylemektedirler.

“Tazminatını da gasp ediyorlar. Ben kendi açımdan söylüyorum, şimdi taşeron firması imza attırıyor bana, boş kâğıda, başlangıç tarihi koyuyor, bitiş tarihini koymuyor, o süre zarfında beni işten attırsa dahi ben kendi isteğimle işten ayrılmış görünüyorum, ben her türlü hakkımı aldım diye yazı yazdırıyor. Sonra sen mahkemeye gitsen bile elin boş dönüyorsun. Türkiye'de yasalar var, denetleme yok" (32 yaşında, 7 yıldır madende çalışıyor, şirket işçisi, lise mezunu, babası madenden emekli, evli, eşi çalışmıyor).

Son yıllarda sayıları hızla artan özel şirket işçileri ile kamu işçileri arasındaki hak temelli farklılıklar şirket işçilerini rahatsız etmekte ve aynı işe aynı ücreti alamıyor olmak şirket 
işçilerini üzmektedir. $\mathrm{Bu}$ kamu/özel ayrımından kaynaklı özellikle ekonomik kayıplar kabul edilmemekte bu bir gerilim noktası üretmektedir. Hem devlet hem de şirket deneyimi olan işçiler vardır. Bu işçiler devletten emekli olmuştur ama şirkette genel olarak deneyimleri yüksek olduğu için yeniden çalışmaya başlamışlardır ve onların yaptı̆̆ 1 karşılaştırma özelleştirme nedenlerini haklılaştırır niteliktedir. Devletin iyi denetlemediği, devlette çalışan işçilerin çeşitli torpiller bularak rahat davrandıkları bu anlamda özel sektörün devreye girmesinin doğru olduğu belirtilmektedir:

“Ya işte devlet başıboş dolaniyor. Neden başıboş dolanıyor? İşte Ahmet falan partinin adami, Mehmet genel müdürün adamı, şu hafif işte çalışsın, bu şurada çalışsın. Kayırma çok devlette. Zaten devlet buradan zarar ediyor Şirkette bu yok. Özel sektörde herkes bir noktaya odaklanır. Nedir bizim bu ayki üretimimiz 85bin ton. Ama devlette bu işte 10 bin çımış 20 çıkmış umursamaz (1984-2000 yılları arası devlette çalışıp emekli olmuş ve şu anda şirkette başçavuş olarak çalışan işçi).

Maden işçiliği konusunda özelleşme ile beraber oluşan devlet işçisi- özel şirket işçisi karşılaştırması işçiler arasında bir ikilik ortaya çıarmıştır. Özel sektör işçileri için devlet işçilerinin çalışma koşulları, ücretleri, iş güvenlikleri referans teşkil etmektedir. Özel sektör ise çok acımasızdır, ücretler düşüktür ve onu bile düzenli ödememektedir. Özel sektörde çalışmanın nedeni ise çaresizlik ve yaygın işsizliktir.

\section{2. 3 Dayanışmadan ayrışma ve çatışmaya}

Eski yıllarda Tunçbilek çok daha canlı, sosyal yaşamı olan, madenin örgütlediği ve belirlediği bir ortam olmuşsa da "güzel yıllar" olarak geçmişte kalmıştır. O vakitler balolar, piknikler, yemekler, düğünler büyük bir katılım ve keyifle yapılır ve tüm ilçenin can damarı olma özelliğini taşırken şimdi artık öyle değildir. Eskiden insanların çalıştıkları çevrede yaşadıkları ve bu nedenle daha çok vakit geçirebildiklerini, birlikte daha fazla sosyalleştiklerini belirtmektedirler. Ama zaman içinde çalışan kişi sayısının azalması, özel sektörün devreye girmesi, Türkiye'nin farklı bölgelerinden kapanan ocaklardan yöreye dışından olan işçilerin göç ile gelmesi ile Tunçbilek'te işçilik kültürü zayıflamaya başlamıştır. Bu arada madene bağlı olarak Tavşanlı'nın gelişmesi okul, hastane ve diğer sosyal olanaklar için ilçenin güçlenmesi, başlamıştır. Eskiden "çalışma ve ortak yaşam" aynı alanda olurken artık maden çalışma, ilçe yaşama alanına dönüşmüştür. Sayılan tüm nedenler birleşerek eski ve yeni işçiler arasında iş̧̧i/madenci dayanışması da zayıflamıştır. Örneğin, servis otobüslerinden özel şirkete çalışan taşeron iş̧̧ilere yer verilmemesi gibi olaylar anlatılmaktadır. Eski maden işçileri arasında KPSS sınavı ile işe giren yeni memur statülü genç işçilerin "madenci olarak kabul edilemeyeceği", madenciliğin ancak içine doğulan bir iş türü olduğu yargıları yaygındır. Artan iş kazalarının bu yeni işçiler yüzünden olduğu ileri sürülmektedir. Halbuki maden işçisi için öncelik işletmede her yerde yazan "önce emniyet" tir. Bu anlamda hem maden işyerinde hem de maden dışında toplumsal yaşamda bir ayrışma deneyimlenmektedir.

Özelleştirilen alanlarda ise şirketlerin gelmeye başlaması ve şirketin olanaklarının daha az olması, kamunun istihdamının belirli sınavlara tabi olması nedenleri ile dışarıdan gelip çalışmaya başlayanların sayısı artmaya başlamıştır. İlçede işsizliğin yüksek olması, maden dışında istihdam olanaklarının sadece madene bağlı tüketim sektörü ile ilişkili olması, ticaret, sanayi ve tarımın düşük istihdam kapasiteleri nedeni ile son ylllarda dışarıdan gelip yerleşmeye ve madende işçileşenlere dair çeşitli önyargılar gelişmekte ve bu durum "onların ekmeğine göz dikme" olarak algılanmaktadır.

\section{2. 4 Özelleştirme sonrası sendika}

Şirkette çalışan ve genç olan işçiler için sendika pek anlamlı bir kurum olarak kabul 
edilmemektedir. Sadece yemek parası, servis kullanımı gibi konularda ve gayet kısıtlı olarak çeşitli katkısının olduğu düşünülmektedir.. Zira özel şirkette çalıştıkları için işte kalabilmelerinin tek olanağı işi yapmaktır. Şayet işlerini iyi yapmazlarsa şirketin onları çıkaracağını bilmektedirler. Bu koşullarda iş güvenliği konusunda sendikanın şirket üzerinde bir etkisinin olmayacağ 1 düşünülmektedir. Özel sektör iş güvenliğini çok da gerekli olmayan bir yapı olarak düşünmektedir. Özel şirkette iş güvenliği işi tam ve düzgün yapmaya, işveren ile iyi ve uyumlu ilişkiler içinde olmaya bağlıdır. Bu nedenle sendika önemsiz hatta bazı durumlarda tehlikeli bir yapiya dönüşebilmektedir.

"Ya devlette olursan sendikanın faydasını hissedersin de özel sektörde olunca pek bir fark yok. Sendika olsun olmasın, işten atmak istese hiç gözünün yaşına bakmiyorlar" (36 yaşında, lise mezunu, yer altı işçisi, şirkette işçi, Tavşanlı, evli).

Özel sektör işçileri iş güvencesi sağlaması açısından sendikayı çok önemsemektedirler. Ayrıca işçiyi yalnız bırakmaması, işçinin yanında olması ve işçi haklarını koruması açılarından da önemsenmektedir.

"Sadece para kesiliyor başka hiçbir katkısı yok yani. İşten çıkarma gibi bir durum olduğunda kalkıp sendika senin hakkını aramıor. Sendika kendi hakkını arıyor, devlet işçisinin hakkını arıyor. Ne kadar da olsa üvey evlatsın yani, ne kadar da olsa dişliyorlar" (27 yaşında, sanat okulu mezunu, 4 yıldır yer altı işçisi, şirket işçisi, bekar, Tavşanl1).

Genel olarak şirkette çalışan işçilerin sendikaya ilişkin görüşleri olumsuz nitelikte gözükmektedir. Kamuda çalışan işçiler için sendikanın anlamlı olduğu ancak kendi iş deneyimleri dikkate alındığında faydalı bir yapı olmadığını düşünmektedirler. İşsizliğin yüksek olması, sendikanın, sendikaya ihtiyacı olmayan devlet işçileri için var olduğu ancak kendileri için pek de bir şey yapmadığ 1 düşünülmektedir.

\section{"Sendika eskisi gibi işverene yüklenemiyor, dediğini yaptıramıyor. Türkiye'de işsiz çok çünkü" (42 yaşında, ilkokul mezunu, yer altı işçisi, özel şirkette çalışıyor, Tavşanlı, evli).}

\section{Tartışma ve Sonuç}

Bu çalışmada, Türkiye'nin önemli maden alanlarından biri olan Tunçbilek kömür işletmelerinin yarattığ 1 sosyal etkiler ve işletmelerde çalışan işçilerin işçilik deneyimleri anlaşılmaya çalışılmıştır. Öncelikle kömür madeni işletmesi kurulmadan önce küçük bir belde olan Tunçbilek ve civar köyleri madenin işletilmeye başlaması ile radikal değişim sürecine girmiştir. 1940'lı ylllardan itibaren madencilik faaliyetlerinin başlaması, 1960'lı yıllarla birlikte termik santralin kurulması ile belde hızla gelişmeye ve değişmeye başlamıştır. 1940-60'1 y yllar kırdan kente göçün başladığı ve kırın çözüldüğü yıllardır. Ancak Tunçbilek'de madencilik faaliyetlerinin başlaması ile iç göç hatta dış göç yaşanmamıştır. Böylece Tunçbilek nüfusu hızla artmaya başlamış, hem maden hem de termik santralde çalışan değişik eğitim, beceri düzeyinde insanlar buraya gelmeye başlamıştır. Görüşmecilerin de değindiği üzere sinemaları, lojmanları, lokalleri, kooperatifleri ile tam bir maden kasabası olmuş, canlı bir cazibe merkezi niteliği kazanmıştır. O yıllar Tunçbileğin çok geliştiği sosyal ve ekonomik açıdan hızla kalkındığı yıllar olarak aktarılmaktadır. Ancak 1980'11 y1llarla birlikte uygulanmaya başlayan ve Türkiye açısından 1990'lı yıllarla birlikte etkileri görülmeye başlayan yeni-ekonomi politiğin etkisi altında kamunun daraldığı ve özel girişimciliğin desteklendiği bir sürece girilmiştir. Özelleştirmelerin hız kazandığı bu dönemde madencilik sektörü de bu gelişmelerden etkilenmiş ve 2000'li yıllarla birlikte sektördeki özel girişimlerin payı artmaya başlamıştır. 
Böylece kamu işçilerinin emekliye sevk edilmesi ve yerine daha az sayıda işçi alınmaya başlanması ve sektördeki özel girişimin payının artması Tunçbilek beldesini derinden etkilemiştir. İşletmelerde çalışan işçi sayısının 15 binlerden 3 binlere düşmesi, kamunun önceliğinin ve katkısının azalması ile birlikte Tunçbilek eski günlerini, gücünü ve cazibesini yitirmeye başlamıştır. Eskiden insanlar hem Tunçbilekte çalışmış hem de burada yaşamış olduğu dönemlerde topluluk bilinci oluşmuş, kalabalık ve güçlü olduklarını anlamışlardır. Ancak hem sayısal ve hem de kamu kaynaklarının azalmasına bağlı olarak belde nüfus kaybetmiştir. Ayrıca kamu kaynaklarının azalması, kamunun eski verdiği önemi vermemeye başlaması eğitim, sağlık, çevre gibi hizmetlerin gerilemesine de yol açmıştır. Böylece özellikle gelir düzeyi daha iyi olan gruplar buradan ayrılmaya ve Tavşanlı'ya yerleşmeye başlamıştır. Böylece Tunçbilek hem çalışma hem de yaşama alanı olduğu zamanlardaki gücünü ve bunun ürettiği dayanışma kapasitesini yitirmeye başlamıştır. Yaşam alanı olarak önemi azaldıkça, buna ilişkin hizmetler de gerilemiştir.

Sosyal etkilerinin dışında kamunun payının azalması, şirketlerin payının artması işçiliği de derinden etkilemiştir. Madencilik sektörü uzun yıllar kamu mülkiyetinde kaldığından ve madencilik ağır ve zor bir iş olarak tanımlanmış olduğundan kamu işçilerine iyi ücret ve iyi çalışma koşulları hazırlama yönünde öncü olmuştur. Madencilik alanında faaliyet gösteren Maden İş sendikası da yaklaşık 12-15 bin iş̧̧inin verdiği güçle sektörün iyileşmesi, temel çalışma koşullarının gelişmesi ve ücretlerin arttırılması, iş güvenliğinin ve işçi sağlığının korunması yönünde etkili şekilde çalışmıştır. Bu işletmelerde işçilik bilinci gelişen işçiler madencilik işinin "iyi iş" olması yönünde ciddi gelişmeler kaydetmişlerdir.

Ancak 1990'lı y1llarla birlikte özelleştirme bir yandan, yeni işçi alımının azaltılması ve resen emeklilik sürecinin işletilmesi ile azalan işçi sayısı ve böylece etkinliği azalan sendika ve teknolojik gelişmeye bağlı olarak mekanize sistemlerin devreye girmesi ile insan gücüne olan gereksinimin azalması birleşerek madenciliği "asgari ücretli", "dönemsel/geçici" bir işe dönüştürmüştür. Şirketlerin sektörde yer almaya başlaması ile ücretler düşmüş, iş güvencesi gitmiş, çalışma koşullarını denetleyen mekanizmalar zayıflamıştır. Sendikanın şirketler üzerinde yaptırımı çok sınırlı kalmış, şirketlerin istihdam garantisi vermiyor olması ise bu iş koşullarında işte başarılı olma, yaptığı işte etkili olma, yaptığı işten gurur duyma gibi duyguların yitirmiş bir işçi üretmiştir. Genel olarak işsizliğin yüksek olması ve Tunçbilek ve civar köylerde yaşayanların çalışmak için başvurabilecekleri başka alternatiflerinin olmaması düşük ücretli, güvencesiz ve tehlikeli işçiliği seçmeyi zorunluluk haline getirmektedir. Şirket işçileri durumlarını "kölelik" olarak açıklamakta ve çaresiz oldukları için katlanmak zorunda olduklarını söylemektedirler. İşçileri koruyabilecek hiçbir mekanizma yok gibidir. Ayrıca tüm bu koşullara rağmen bu işte çalışmak isteyen bunun için tanıdık desteği bulmaya çalışan hatta rüşvet veren insanlar vardır. Özel şirketler karlılığı esas aldıkları için işçiye, madene ve çevreye gerekli yatırımı yapmak istememektedirler. Öte yandan, yeni taşeron işçilerde işe saygı ve bağlılık duyamadıkları için daha kaderci olmakta ve böylece iş kazaları artmaktadır. Ancak işçiler iş kazalarında bile şirketi suçlayamamakta, oldukça korumasız, desteksiz ve güvencesiz koşullar altında çalışmayı kabul etmek zorunda kalmaktadırlar.

Tunçbilek kömür işletmesi çalışması bize madenlerin özelleştirilmesi, yeni teknolojilerin gelmesi ve iç göç yolu ile bölgeye gelen taşeron işçiliğin ortaya çıkardığ1 değiş̧en işçilik biçimlerini ve işçiler arasındaki ayrışmanın nedenlerini göstermektedir. Yeni toplumsal yaşamda bu ayrışmanın izlerini taşımakta ve eski ve yeni işçilerin oluşturduğu mahallelerde farklı yaşam biçimleri ve pratikleri oluşmakta, birbirine benzeyen ve "biz duygusu" olan işçilik giderek yok olmaktadır. 


\section{Kaynakça}

Ackers, P. ( 1996), Life after death: mining history without a coal industry, Historical Studies in Industrial Relations 1, pp159-70.

Ackers, P.andPayne, J. (2002), Before the storm: the experience of nationalization and theprospects for industrial relations partnership in the British coal industry, 1947-1972 - rethinking the militant narrative, Social HistoryVol. 27 No. 2, ss.184-209.

Baiman, Ron, HeatherBoushey ve DawnSaunders (2000), Political Economy and Contemporary Capitalism, Londonand New York: M.E. Sharpe.

Bello, Walden, NicolaBullard ve KamalMalhotra (2000), Gloabl Finance: New Thinking On Regulating Speculative Capital Markets, London ve New York: ZedBooks.

Bulmer, M. (1975), Sociological Models of Mining Community, Sociological Review, 23, pp.61-92.

Bulmer, M. (ed.) (1978), Mining and social change: Durham County in the twentieth century, CroomHelm: London.

Dennis, N.,Henriquesand C Slaughter(1956), Coal is Our Life: an analysis of a Yorkshire miningcommunity, Tavistock: London.

Dersan, N. Ve Tuğrul, İ. (2004), Tavşanl1-Tunçbilek Havzası Ömerbey Mahallesi Alan Araştırması, DevMaden Sen, Kırsal Kalkınma Dizisi, No: 3, Ankara.

Gibbon,P. And Bromley,S. (1990), '"From an institution to a business"? Changes in the British coal industry 1985-9,. Economy and Society, 19: pp. $151-160$

Leman, S. And Winterton, J. (1991), 'New technology and the restructuring of pit level industrial relations in the British coal industry,. New Technology, Work and Employment, 5:pp.. 54-64.

Kepenek, Y. ve Yentürk, N. (2011), Türkiye Ekonomisi, 24. Basım, Remzi Kitapevi, İstanbul.

Kıray, M. (1964), Ereğli: Ağır Sanayiden Önce Bir Sahil Kasabası, Bağlam Yayınları, Ankara.

Maden Mühendisleri Odası: Madencilik Sektörü ve Politikaları raporu, Mart, 2011, Ankara.

Makal, A. (2004), Zonguldak ve Türkiye Toplumsal tarihinin ac1 bir deneyimi olarak "iş mükellefiyeti", Zonguldak Kent Tarihi Bienali Bildiriler Kitabı, İstanbul, ss. 69-91.

Makal, A. (1999), Türkiye'de tek partili dönemde çalışma ilişkileri: 1920-1946, İmge Kitapevi, Ankara.
Parry, D. Et. Al. (1997), Industrial Relations in the Privatized Mining Industry, British Journal of Industrial relations, 35:2, pp.173-196.

Petras, James ve Henry Veltmeyer (2001), Globalization Unmasked: Imperialism in the 21st Century, London and New York: ZedBooks.

Putnam, R. (1995), Bowling Alone: “America's Declining SocialCapital," Journal of Democracy 6: pp..65-78

Richards, A. J.,(1996), Miners on strike: class solidarity and division in Britain, Berg, Oxford.

Roberts, I.,(1993), Craft, class and control: the sociology of a ship building community, Edinburg University Press, Edinburg.

Strangleman, T, (2001), Networks, place and identities in post-industrial mining communities, International Journal of Urban and RegionalResearch, Vol.25:2, pp. 253-266.

Simpson, S.,(1988), A trade union solidarity: memoir of a mid-nineteenth century miner, History Workshop Journal 25, pp.148-65.

Supple, B.,(1987), 1914-1946:The Political Economy of Decline, TheHistory of the British Coal Industry, Vol. 4, pp. 682-3.

Tamzok, N.,(2003), Osmanlı İmparatorluğu'nun son döneminden çok partili döneme madencilik politikaları, Ankara Üniversitesi SBF Dergisi, ss.63-64.

Tamzok, N.,(2007), Küreselleşme' Serbestleşme ve Kömür Endüstrisi, Türkiye VI. Enerji Sempozyumu, 22-24 Ekim.

Tamzok, N. (2003), “Küresel Politikalar ve Türkiye Madencilik Sektörü", Neo-liberal Politikalar ve Kamu Yönetimi Sempozyumu Bildiriler Kitabı, KİGEM, Ankara.

Turan, M.,(1983), Madenciliğimizin Tarihsel Gelişimi, Cumhuriyet Dönemi Türkiye Ansiklopedisi, İstanbul: İletişim Yayınları.

Turner, R, (2000), Coalwasour life, Sheffield HallamUniversity: Sheffield.

Ulutan, B.,(1987), Etibank, 1935-1985, Ankara.

Williamson, B,(1982), Class, culture andcommunity: a biographical study of social change in mining, Routledge and Kegan Paul: London.

World Energy Council (WEC) (2000), Restructuring and Privatizing the Coal Industries in Central and Eastern Europe and the CIS, London 